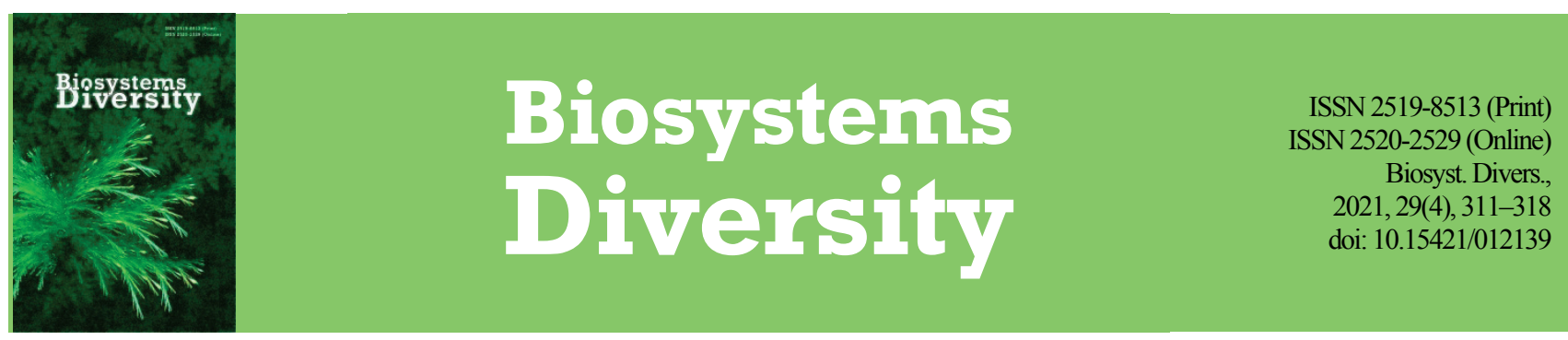

\title{
Variability of the structure of winter microbial communities in Chelyabinsk lakes
}

\author{
S. V. Andreeva, Y. Y. Filippova, E. V. Devyatova, D. Y. Nokhrin \\ Chelyabinsk State University, Chelyabinsk, Russia
}

Article info

Received 15.10.2021

Received in revised form 17.11.2021

Accepted 18.11.2021

\author{
Andreeva, S. V., Filippova, Y. Y., Devyatova, E. V., \& Nokhrin, D. Y. (2021). Variability of the structure of winter microbial communities \\ in Chelyabinsk lakes. Biosystems Diversity, 29(4), 311-218. doi:10.15421/012139
}

Microorganisms form complex and dynamic communities that play a key role in the biogeochemical cycles of lakes. A high level of urbanization is currently a serious threat to bacterial communities and the ecosystem of freshwater bodies. To assess the contribution of anthropogenic load to variations in the structure of winter microbial communities in lakes, microorganisms of four water bodies of Chelyabinsk region were studied for the first time. We used cultural, chromatography-mass spectrometric, and modern methods of statistical data processing (particularly, multivariate exploratory analysis and canonical analysis of correspondences). The research showed that the composition of winter microbial communities in lakes Chebarkul', Smolino, Pervoye, and Shershenevskoye Reservoir did not differ significantly between the main phyla of microorganisms. The dominant microorganisms were found to be of the Firmicutes phylum and Actinobacteria phylum. The structure of bacterial communities had special features depending on the characteristics of the water body and the sampling depths. Thus, in the lakes Smolino, Pervoye, and Shershenevskoye Reservoir, an important role was played by associations between microorganisms - indicators of fecal contamination: coliform bacteria and Enterococcus. On the contrary, in Chebarkul' Lake, members of the genus Bacillus, which are natural bioremediators, formed stable winter associations. However, the differences between water bodies and sampling depths reflected $28.1 \%$ and $9.8 \%$ of the variability of the winter microbial communities, respectively. The largest contribution (about 60\%) to the variability of the structure was made by intra-water processes, which determined the high heterogeneity of samples from different water areas. We assume that an important role in this variability was played by the high anthropogenic impact in a large industrial metropolis. In our opinion, this line of research is very promising for addressing key environmental issues.

Keywords: water of surface water bodies; microbial communities of water bodies; anthropogenic load; canonical correspondence analysis; industrial megalopolis lakes.

\section{Introduction}

Communities of microorganisms are fundamental components of the aquatic environment. They are extremely diverse and play a key role in managing global energy flows and biogeochemical cycles (Ren et al., 2017; Qu et al., 2018; Yadav et al., 2018). In marine, lake, and river ecosystems bacteria (1) actively influence the flow of carbon, nitrogen, phosphorus, sulfur, and organic compounds, (2) take part in biodegradation of pollutants (for example, polycyclic aromatic hydrocarbons, remineralization, and circulation of inorganic compounds), and (3) are the main food source for other organisms (such as protozoa) (Zhang et al., 2019; Reid et al., 2020; Yue et al., 2020). Moreover, microorganisms have a high response rate to changes in environmental conditions, which gives them value as indicators of water quality and ecosystem condition ( $\mathrm{Ji}$ et al., 2019; Sagova-Mareckova et al., 2021). Therefore, taxonomic and functional changes in microbial communities in lake water can lead to disturbances in ecosystem processes (David et al., 2021; Xie et al., 2021).

Today, vast and expanding urbanization is hazardous to the ecosystem of water bodies (Liu et al., 2021). The rate at which urban areas around cities grow are exceeding the rate of population growth (Li et al., 2021), which worsens the hygienic properties of fresh water and, consequently, human health (Xie et al., 2021). Anthropogenic transformation of lakes leads to the introduction of non-typical bacteria (including fecal) into the water systems and can change the natural composition of the microbial community of freshwater (Numberger et al., 2019; Cao et al., 2020; Yang et al., 2020). Normally, communities of natural microorganisms are able to limit the growth of pathogens sporadically polluting water bodies. However, in lakes that are subjected to a strong anthropogenic load, new communities are appearing that are favourable for the survival and spread of pathogens (Falk et al., 2019; Mathai et al., 2019; Beattie et al., 2020).

Alternatively, it is known that aquatic communities of microorganisms are very dynamic and can undergo rapid changes in composition, even over several days. The abundance of microorganisms can be determined by natural environmental and climatic factors such as (1) temperature, (2) the degree of photosynthetically active radiation penetration, (3) water salinity, (4) the level of dissolved oxygen, (5) the amount of organic and nutrient substances, etc. (Butler et al., 2019; Yue et al., 2020; David et al., 2021). Therefore, the question of which human activities affect the overall structure and diversity of the microbial community in freshwater lakes remains mostly unknown (Cavaco et al., 2019; Nnadozie \& Odume, 2019; Yang et al., 2020).

To evaluate the complex impact of industrial (wastewater and aerial emissions from factories, and the wastes from highways) and municipal (wastewater treatment plants and storm sewers) anthropogenic impacts, we studied microbial communities of lakes in Chelyabinsk city. Chelyabinsk is one of the industrial metropolises of Russia, with a population over a million and a developed energy sector. There are more than eight large enterprises of ferrous and non-ferrous metallurgy in the city and the largest machine-building plants for tractors, automatic machines and several others. The city is an important transport hub, lying between the Asian and European parts of Russia.

Lakes Smolino and Pervoye receive technical wastewater from industrial enterprises, storm sewers and have intensive flat runoff from the asphalted areas of the city. Both reservoirs have increased mineralization (TDS about $1,000 \mathrm{mg} / \mathrm{L}$ ) and high proportions of $\mathrm{Na}^{+}$and $\mathrm{Cl}^{-}$in their composition. In terms of self-purification capacity, Pervoye Lake is a $\beta$ mesosaprobic water body (Serebrennikova, 2010), and Smolino Lake is an $\alpha$-mesosaprobic water body with the transition to a polysaprobic one (Zakharov \& Likhachev, 2008). Shershenevskoye Reservoir is a source of drinking water supply in Chelyabinsk (TDS $=303 \mathrm{mg} / \mathrm{L}$ ). According to its hydrobiological and hydrochemical parameters, it is a $\beta$-mesosaprobic water body (Deryabina et al., 2008; Nokhrin et al., 2020). All water bodies of the Chelyabinsk group are subject to some degree of anthropogenic eutrophication (Zakharov, 2010). We used Chebarkul' Lake for compari- 
son. It is located in a recreational area $-95 \mathrm{~km}$ from Chelyabinsk (TDS about 450-480 mg/L) (Zakharov, 2014; Nokhrin et al., 2018). This reservoir is distinguished by its high self-purification capacity: due to the shape of the basin, which causes wind mixing to a depth of $8-9 \mathrm{~m}$, and a long period of autumn homothermy, the bottom waters are well supplied with oxygen (Zakharov, 2014).

The aim of the research is to characterize the variability of the winter microbial communities in water bodies of Chelyabinsk region with different levels of anthropogenic load.

\section{Materials and methods}

Water sampling was carried out from January 28, 2021 to February 6, 2021, at four water bodies in Chelyabinsk region (Fig. 1). Samples were taken from three levels (surface, middle, and bottom). The depth at the sampling points varied from 1.7 to $7.3 \mathrm{~m}$ (average is $3.7 \mathrm{~m}$ ). The water temperature varied from 0.6 to $8.7^{\circ} \mathrm{C}$ (average is $4.2{ }^{\circ} \mathrm{C}$ ). Water was taken using a bathometer into sterile polypropylene bottles, following the asepsis requirements. The collected water samples were marked and delivered to the laboratory in an ice box at a temperature of $4-10^{\circ} \mathrm{C}$ within $2-$ 6 hours after collection.

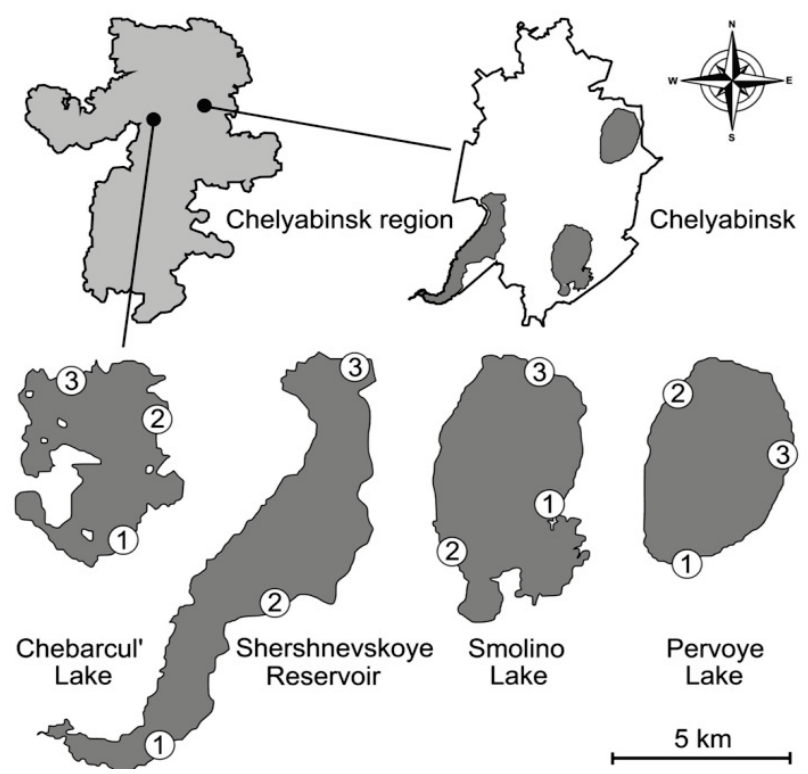

Fig. 1. Water sampling points in Chelyabinsk region water bodies in the winter of 2021

The concentration of water samples was carried out by the method of membrane filters on a "PVF 43/3 NB" vacuum filtration device (Baromembrannaya technologia LLC, Russia, 2020) using cellulose membranes with a disc diameter of $47 \mathrm{~mm}$ and a pore size of $0.22 \mu \mathrm{m}$ (Millipore, USA, 2020). After filtration, the membranes were placed on different selective nutrient media: Endo, bismuth-sulfite agar, salt egg yolk agar, uriSelect agar, thiosulfate-citrate-bromothymol sucrose agar, ironsulfite medium, Sabouraud agar, and others. Next we determined the taxonomic status of the microorganisms based on a set of biochemical traits using test systems manufactured by LaChema (Czech Republic, 2020): NEFERMtest, ENTEROtest, STREPTOtest, and STAPHYtest according to the instructions.

The method of gas chromatography-mass spectrometry of microbial markers (GC-MSMM) proposed by Osipov et al. (2009) was used to detect uncultivated, slowly growing, and difficult to cultivate microorganisms. The membrane was obtained after the water samples were concentrated using the membrane filter method, then the membrane was dried in methanol, subjected to acid methanolysis, extracted using hexane, and treated with N,O-bis(trimethylsilyl)trifluoroacetamide. The resulting mixture of ethers was analyzed using a Maestro gas chromatography-mass spectrometer (Interlab LLC, Russia) on an HP-5ms capillary column (Hewlett-Packard, USA). The following are the conditions for chromatographic separation:
- initial temperature $-130^{\circ} \mathrm{C}$

- exposure $-0.5 \mathrm{~min}$;

- heating $-70^{\circ} \mathrm{C} / \mathrm{min}$ to $320^{\circ} \mathrm{C}$;

- exposure at the final temperature $(6 \mathrm{~min})$;

- selective ion mode;

- helium carrier gas, flow $-1.2 \mathrm{~mL} / \mathrm{min}$, without flow separation.

We determined the presence of microorganism markers using a standard mass spectrometer database. We recalculated the areas of peaks of substances into the number of microorganisms using the program developed by Interlab LLC.

During the statistical analysis of the obtained data, we used sample comparisons and multivariate EDA. To compare water bodies by the relative ratio of taxa, we combined the data on the number of species in a $4 \times 5$ contingency table and analyzed it using the chi-square test. P-value was calculated by the Monte Carlo permutation test $(n=9999)$. Analysis of the contribution of individual cells of the table was performed using Freeman-Tukey deviations FT $_{\text {dev }}$ (Sokal \& Rohlf, 1995).

Dependence of the microbial community composition from the following factors "Reservoir," "Depth" and "Reservoir + Depth" was analyzed using the Canonical Correspondence Analysis (CCA) ordination technique in "vegan" package (version 2.5-7) for the statistical software environment R (version 4.0.3) (R Core Team, 2016) and in "PAST" package (version 4.05) (Hammer et al., 2001). For this, columns of dummy variables (contrasts) were added to the matrix of species composition data, indicating the presence $(1)$ or absence $(0)$ of this nominal predictor. Graphic constructions were performed in the "PAST" and "TpX" packages (version 1.5) (CTAN, 2008). Statistically significant effects were considered at $\mathrm{P}<0.05$ in the randomized analysis of variance (permutation ANOVA) $(\mathrm{n}=9999)$.

\section{Results}

Using a combination of the classical cultural method and the GCMSMM method, 42 operational taxonomic units (OTU) were identified in the winter communities of microorganisms in four lakes of Chelyabinsk region. They belonged to four bacterial phyla (Bacteroidetes, Firmicutes Actinobacteria, and Proteobacteria) and fungi kingdom (members of the genus Aspergillus and Candida). Among them, 21 OTU were identified as species and 21 as genus.

Comparison of water bodies to their relative ratio of taxa in microbial communities showed no differences $\left(\chi_{(12)}^{2}=6.02 ; \mathrm{P}_{\mathrm{MC}}=0.926\right)$. Bacteria of the Firmicutes phylum were predominant in all lakes in winter. However, the composition of the microbial community of Chebarkul' Lake (low anthropogenic load) differed from the composition of lakes with high anthropogenic load by a significantly low occurrence of bacteria of the Proteobacteria phylum: $\mathrm{FT}_{\mathrm{dev}}=-1.79 ; \mathrm{P}=0.021$. Moreover, this reservoir was characterized by slightly greater proportions of species belonging to the Actinobacteria and Bacteroidetes phyla (Fig. 2).

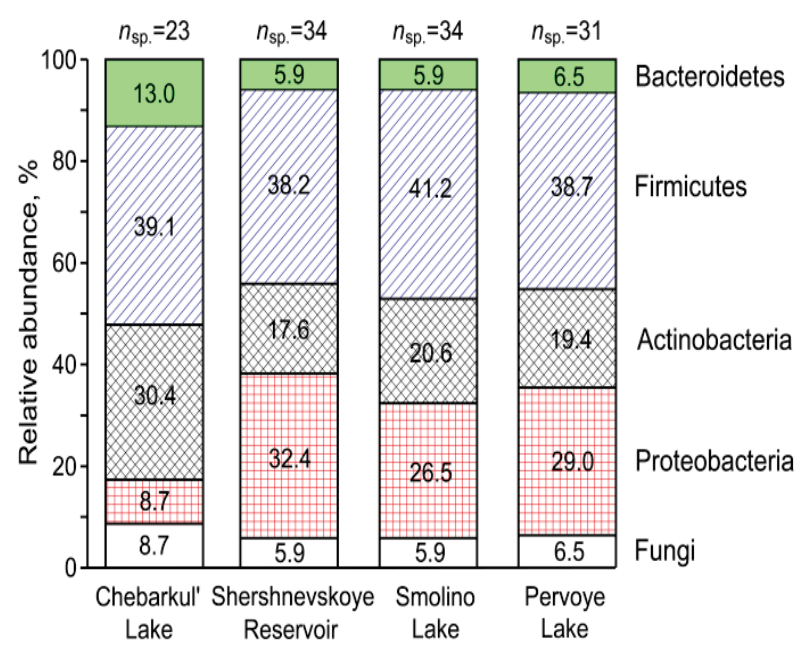

Fig. 2. Absolute (nsp.) and relative (\%) abundance of microorganisms' taxa in the studied water bodies 
The properties of the detection methods did not allow us to determine the microorganisms of the Archaea and Cyanobacteria taxa commonly found in water.

To study the differences in the microbial community's structure in water bodies, we used the CCA method. This is the constrained multivariate ordination technique that allows us to extract the specific components of variability (inertia) among all the variability, specified by a set of regressors controlled by the researcher. In our case, such regressors were "Reservoirs" and "Depths", which were analyzed separately. Analysis with the inclusion of 4 water bodies, 3 canonical axes were identified, explaining $28.1 \%$ of the total inertia (Fig. 3 , 4). This model was statistically significant $\left(\mathrm{F}_{(3 / 2)}=4.16 ; \mathrm{P}<0.001\right)$, which indicates the existence of nonrandom differences in the structure of microbial communities in water bodies.

Axis 1 explained $61.1 \%$ of the total inertia and was statistically highly significant: $F_{(1 / 32)}=7.64 ; P<0.001$. As seen from the biplot (Fig. 3), it showed differences between the structures of microorganisms communities in water bodies with a high anthropogenic load (Chelyabinsk lakes) on the one hand and Chebarkul' Lake on the other. The main feature of water bodies located within the boundaries of the Chelyabinsk city was the presence of coliform bacteria (Escherichia coli, Enterobacter spp., Klebsiella pneumoniae, Citrobacter spp., Proteus spp.), Enterococcus (E. faecalis, E. faecium, Enterococcus spp.), as well as members of the genus Vibrio. The main feature of the Chebarkul' Lake microorganisms was strong association of various members of the genus Bacillus and the species not found in any other water body: Yersinia enterocolitica, Eikenella corrodens and Chryseobacterium indologenes. Chebarkul' Lake was characterized by the absence of coliform bacterias, enterococcus, and vibrios (Fig. 3).

Axis 2 explained $24.4 \%$ of the total inertia and was also statistically highly significant: $\mathrm{F}_{(1 / 32)}=3.04 ; \mathrm{P}<0.001$. On this axis, differences between Smolino Lake on the one hand and Shershenevskoye Reservoir and Pervoye Lake on the other were discovered. The main feature of the Smolino Lake community, were members common for saline waters - the association of vibrios (Vibrio non cholera and Vibrio parahaemolyticus) and Ochrobactrum anthropi. The main feature of Shershenevskoye Reservoir and Pervoye Lake were high concentration of Erysipelatoclostridium ramosum, Plesiomonas shigelloides, and Pseudomonas putida (Fig. 3).

Axis 3 (Fig. 4) explained the remaining $14.5 \%$ of the variability in the species composition of the microbiota and was statistically significant: $\mathrm{F}_{(1 / 32)}=1.82 ; \mathrm{P}=0.011$. It determined the differences in the structure of the community of microorganisms between Pervoye Lake and Shershenevskoye Reservoir. As shown from Figure 4, the differences between them were as follows. In Pervoye Lake P. putida was detected, while it was absent in other water bodies and there was a high frequency of Enterococcus spp. In Shershenevskoye Reservoir an association of the following species was found: P. shigelloides, Blautia coccoides, and E. ramosum.

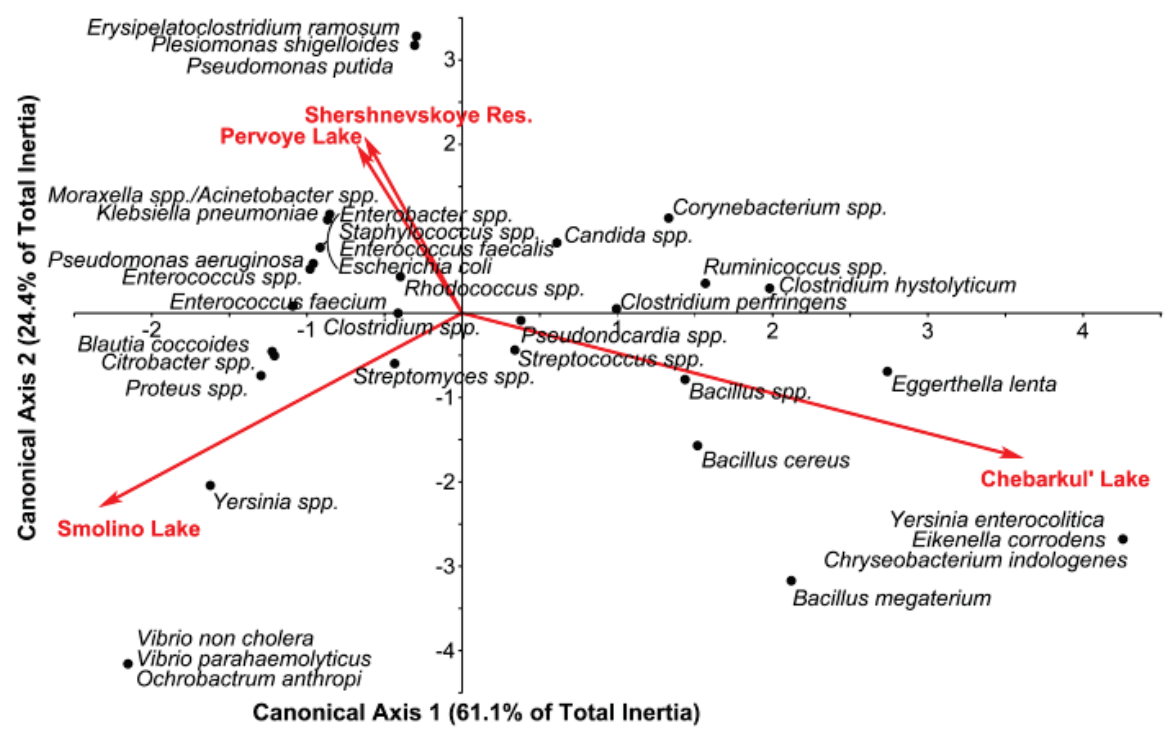

Fig. 3. Microorganisms in the space of 1 and 2 axes of the canonical analysis of correspondences with water bodies as regressors

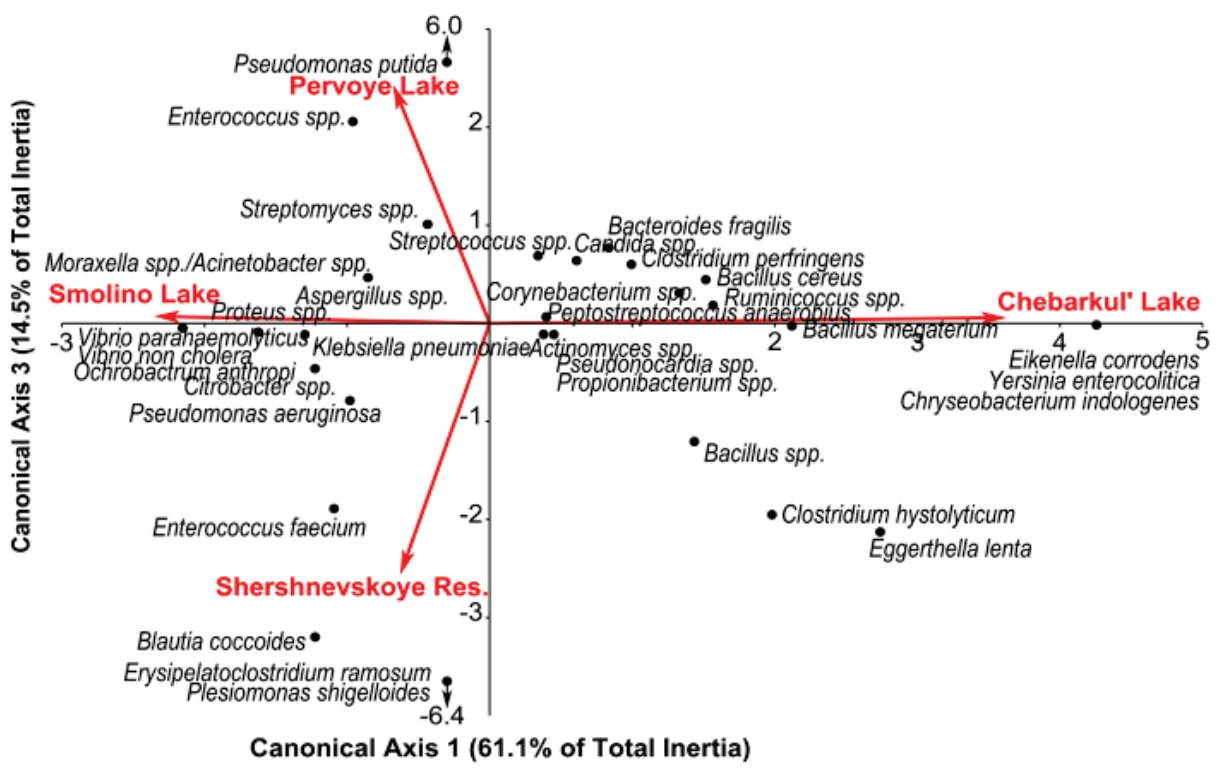

Fig. 4. Microorganisms in the space of 1 and 3 axes of the canonical analysis of correspondences with water bodies as regressors 
According to the same scheme of analysis, CCA was used with three sampling depths as regressors. We found that the depths significantly affect the microbial composition of microbial communities $\left(\mathrm{F}_{(2 / 3)}=1.80\right.$; $\mathrm{P}=0.007$ ) and explain it by $9.8 \%$. Axis 1 explained $76.7 \%$ of the inertia; it was statistically significant: $F_{(1 / 33)}=2.76 ; P=0.005$. As seen from the biplot (Fig. 5), this axis characterized the differences between surface and bottom levels. The middle level occupied an intermediate position, slightly closer to the bottom. Surface water samples showed the presence of the following species microorganism associations: B. coccoides, E. faecalis, $Y$. enterocolitica, and fungi of the genus Candida spp. The main characteristic of the bottom samples was the presence of Chryseobacterium indologenes, E. corrodens, and Streptomyces spp.

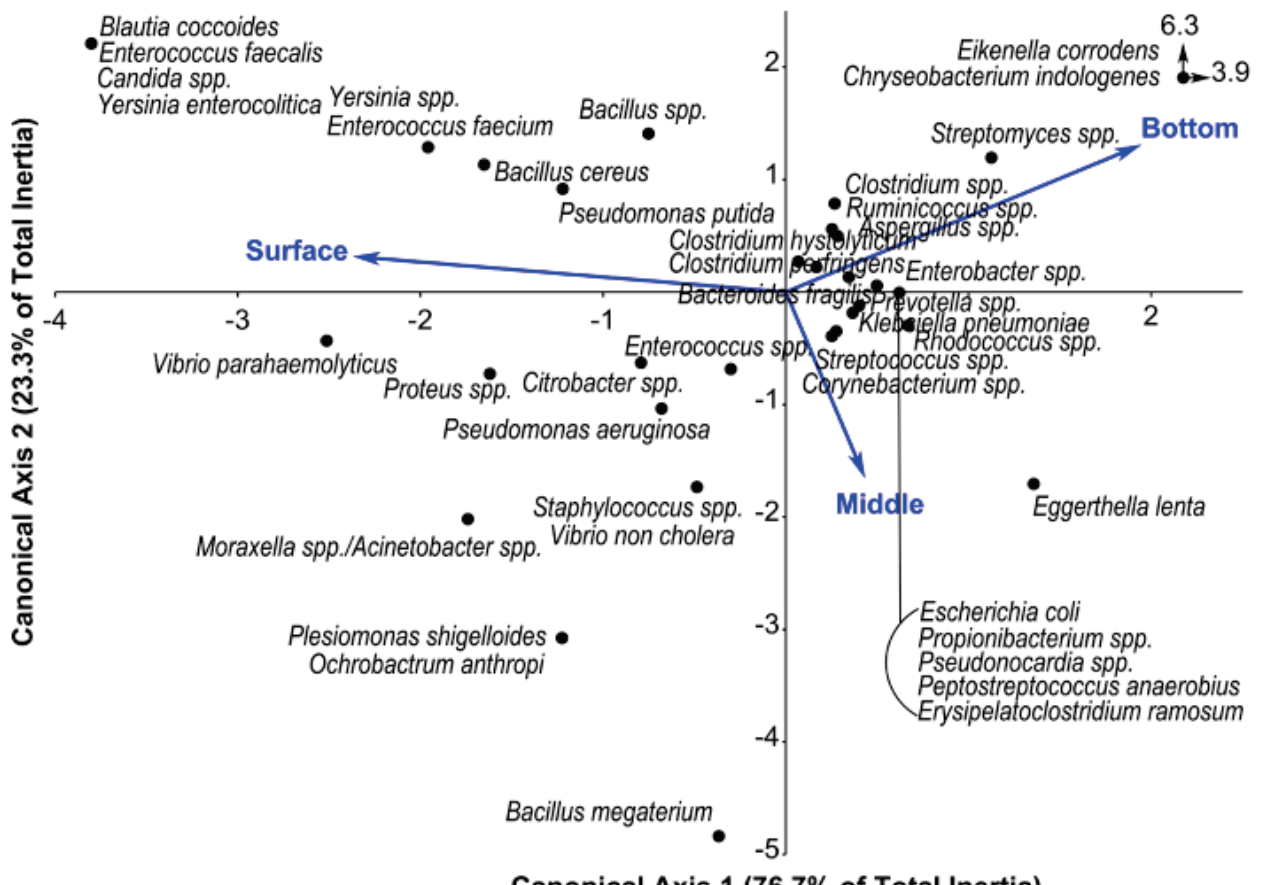

Canonical Axis 1 (76.7\% of Total Inertia)

Fig. 5. Microorganisms in the space of 1 and 2 axes of the canonical correspondence analysis with depths as regressors

The remaining $23.3 \%$ of inertia was on axis 2 , which characterized the differences between the middle and bottom levels but was not statistically significant: $F_{(1 / 33)}=0.84 ; P=0.642$. Therefore, using the two CCA, we found that the factors "Reservoir" and "Depth" determined $28.1 \%$ and $9.8 \%$ of the variability of microbial communities, respectively. The correspondences analysis and its canonical version, as the measure of distance used the chi-square statistics, which doesn't have the property of additivity. That's the reason another analysis was used to assess the cumulative effects of these factors, with the simultaneous appliance of all seven regressors ( 4 water bodies +3 depths). So, we found that water bodies and depths statistically significantly $\left(\mathrm{F}_{(5 / 3))}=3.64 ; \mathrm{P}<0.001\right)$ determine the structure of bacterial communities by $37.8 \%$. This is almost identical to the simple sum of the percentages $(28.1+9.8=37.9)$. The closeness of these numbers indicates the absence of interaction between "Water bodies" and "Depth". Consequently, 62.2\% (100-37.8 =62.2) of the variability of winter microbial communities was due to other reasons, and in our research design, it means only a single source of variation - the differences between sampling points within one water body.

\section{Discussion}

Analysis of the composition of microbial communities of industrial metropolis lakes. The present research shows that members of the phyla in the dominant winter microorganism communities in the industrial metropolis lakes were Firmicutes, Actinobacteria, and Proteobacteria. Similar results were obtained by other researchers (Iliev et al., 2017; Kiama et al., 2021). However, it is interesting to note that in lakes within Chelyabinsk city, bacteria of the Proteobacteria phylum prevailed over microorganisms of the Actinobacteria phylum. Simultaneously, in Chebarkul' Lake, located in the recreational area, the members of the Proteobacteria phylum was the lowest ( 2 out of 15 species found in urban water bodies were identified).

The predominance of Firmicutes and Actinobacteria in the structure of microorganism communities in all the lakes is natural since the taxa included in their composition ensure the decomposition of a wide range of organic and inorganic compounds. This allows the community to perform its functions in low temperatures and the presence of ice cover (Butler et al., 2019; Manikkam et al., 2020; Phulpoto et al., 2021).

Thus, bacteria of the genus Bacillus are autochthonous spore-forming inhabitants of soil and freshwater bodies. They can exist in a wide variety of temperatures in psychrophilic and thermophilic forms and play the role of primary colonizers in aquatic communities (Wu et al., 2017; Huang et al., 2018; Kim et al., 2021). A characteristic feature of these microorganisms is the ability to reduce nitrates in water (Rajakumar et al., 2008), use heavy metals to form spores, thereby reducing their concentration (Yin et al., 2018; Ramírez et al., 2019; Wang et al., 2020), and remove oil spills (Tanzadeh et al., 2020). Thus, many researchers suggest using Bacillus spp. to effect bioremediation of various water bodies from organic pollutants and heavy metals (Kuebutornye et al., 2019; Hlordzi et al., 2020; Sharma \& Shukla, 2021).

Bacteria of the genus Clostridium include psychrophilic, mesophilic, and thermophilic species which are involved in decomposing complex organic substrates into acids, alcohols, and carbon dioxide, hydrogen, and minerals. The ability to form spores resistant to extreme conditions makes them widespread in the environment (Vierheilig et al., 2013; Tadese et al., 2020).

Representative species of the genera Peptostreptococcus, Streptococcus, and Ruminicoccus are part of the normal microbiota of many animals (McLoughlin et al., 2020), including aquatic organisms, they participate in the biological degradation cycles of cellulose, amylose, fats, and ferment amino acids (Chapagain et al., 2019). Due to their frequent occurrence in the intestinal microbiota, they are often found in wastewater (Cyprowski et al., 2018).

Actinobacteria are often the dominant phylum in the surface layer of lakes, as they are relatively resistant to ultraviolet radiation. Actinobacteria are indigenous bacteria in freshwater habitats that can degrade complex organic polymers (such as lignin) or absorb amino acids by metabolizing N-containing aromatic polymers (such as chitin) (Aguilar et al., 2018; Liu et al., 2019; Manikkam et al., 2020). The differences we found in the relative occurrence frequency of proteobacteria may be associated with 
the fact that the members of this phylum belong to a physiologically diverse group of microorganisms. Thus, alpha and beta proteobacteria are considered to be some of the most important aquatic microorganisms on our planet. They often dominate oligotrophic water bodies and can be competitive when nutrient availability is low (Phulpoto et al., 2021; Tian et al., 2021). On the other hand, gamma-proteobacteria (and many potentially pathogenic microorganisms among them) usually require high concentrations of organic matter. Often, the content of gamma-proteobacteria in aquatic communities grows as the population of cyanobacteria increases (Kiersztyn et al., 2019), which was not identified in the current research.

In addition to the three dominant taxa, bacteria of the Bacteroidetes, and specimen of the fungi (genera Aspergillus and Candida) were present in winter communities in all lakes. Bacteroides-Prevotella group is considered to be an indicator of fecal water contamination. This group is used to monitor or determine the spatial and temporal distribution of fecal contamination in the natural aquatic environment (Okabe et al., 2007; Vadde et al., 2019; Nevers et al., 2020).

Members of the Fungi are the main decomposers of organic matter on Earth. They are natural saprophytes that can survive in amoebas and other aquatic organisms, be part of biofilms in water pipes, and cause infections in immunocompromised individuals (Wahl et al., 2018; Hubert et al., 2021).

Heterogeneity of microbial communities structure in water bodies depending on the level of anthropogenic load and the sampling depths. The research identified high variability in the structure of microbial communities between lakes in an industrial metropolis. Each water body had its own characteristics of the bacterial structure.

Chebarkul' Lake, which we took as an arbitrary control water body, demonstrated a community of microorganisms with a high potential for self-cleaning since, it was based on associations of genus Bacillus microorganisms (Bacillus spp., B. cereus, B. megaterium), whose distinctive feature is resistance to extreme conditions (including the low temperatures and low oxygenation in winter). Besides, they are natural destructors of toxic compounds (Alamri, 2012; Müller et al., 2015; Kim et al., 2021). Because of the high bacillus representation in the water body, Chebarkul' Lake had no indicators of fresh fecal contamination (coliform bacteria and enterococcus). However, now the natural rhythm of the lake is disturbed: (1) water is constantly taken from the lake for the household and drinking needs of Chebarkul' city, (2) there is industrial fishing, and (3) health-resorts (Zakharov, 2010). Therefore a stable association of $C$. indologenes with opportunistic microorganisms of the species $Y$. enterocolitica and E. corrodens in the community was detected. To date, it is known that $C$. indologenes is a natural inhabitant of soil and water, vegetates in the aquatic organisms (including protozoa), and is usually not found in the human microbiota. However, it can induce infections in immunocompromised individuals (Alon et al., 2018; Lim et al., 2020). Y. enterocolitica are human pathobionts capable of causing enterocolitis with food or water infection (Fàbrega \& Vila, 2012; Lucero-Estrada et al., 2020; Guillier et al., 2021). Various authors have described E. corrodens as a normal oral inhabitant (commensal subgingival bacteria) commonly found in plaque biofilm in healthy individuals (Penton et al., 2020; Rodríguez-Rojas et al., 2020; Tanaka et al., 2020). It is known that $E$. corrodens can form biofilms on the surface of polystyrene (Azakami et al., 2006), which may indicate its anthropogenic origin.

Smolino Lake, Pervoye Lake, and Shershenevskoye Reservoir are located on the Miass River in Chelyabinsk. These water bodies are subject to serious anthropogenic impact. For a long period of time, wastewater from the city's enterprises was discharged into Smolino and Pervoye lakes. Before they became part of the technological chain of wastewater disposal, they were small-sized, salty and subsaline water bodies. As a result of the industrial wastewater influx (the transformed waters of the Miass River), the water regime of the lakes has changed significantly, and water desalination has occurred: the level of Smolino Lake rose by $3 \mathrm{~m}$, of Pervoye Lake - by $5 \mathrm{~m}$; the area of these water bodies has increased at least two times (Zakharov \& Likhachev, 2008). Shershnevskoe Reservoir is the only source of drinking water in Chelyabinsk. Today, water from lakes Smolino, Pervoye, and Sineglazovo is constantly discharged through spillways into the Miass River basin (Zakharov, 2010). The abundance of coliform bacteria (E. coli, Enterobacter spp., K. pneumoniae,
Citrobacter spp., Proteus spp.) and enterococcus was a characteristic feature of the microbial communities' structure in water bodies within the boundaries of the industrial metropolis. They indicate fresh fecal contamination. Besides, Clostridium perfringens, which was found in all studied water bodies, is a universal component of human and animal intestines, which do not reproduce in most aquatic environments, and serve as a particular indicator of long-standing fecal contamination (Mueller-Spitz et al., 2010; Vierheilig et al., 2013; Cao et al., 2020). The main source of surface water pollution with fecal bacteria can be wastewater from treatment facilities (Beattie et al., 2020; Xie et al., 2021).

According to Zakharov (2010), heavy metal ions are one of the polluting factors of water bodies in Chelyabinsk city. All studied lakes were characterized by the presence of the opportunistic bacterium Pseudomonas aeruginosa, in the structure of the community. Its distinguishing feature is increased resistance to heavy metals (Kumari \& Das, 2019; IzraelŽivković et al., 2019; Ramos et al., 2020). P. aeruginosa is well known in medicine as an antibiotic-resistant causative agent of nosocomial infections, but water is a natural reservoir of this species. $P$. aeruginosa is found in biofilms in water pipes and, as a consequence of the current lifestyle, it reaches relatively high abundance in food and on many wet surfaces (Kang \& Kirienko, 2018; Ramos et al., 2020). Despite its potential pathogenicity, $P$. aeruginosa has a very wide spectrum of enzymatic activity (Huang et al., 2018) and plays an important ecological role in water bodies: it reduces the number of nitrates in lake waters (Rajakumar et al., 2008), demonstrates a high efficiency in removal of crude oil (Huang et al., 2017; Tanzadeh et al., 2020), oils, petroleum products (Varjani et al., 2020; Phulpoto et al., 2021), and heavy metals (Kumari et al., 2019; Izrael-Živković et al., 2019). The presence of this bacterial phylum in water can promote the self-recovering of the polluted industrial water bodies.

Specific to the bacterial structure of Smolino Lake was the presence of Vibrio non cholera, $V$. parahaemolyticus, and $O$. anthropi. Vibrios are quite common in marine environments, estuary waters, and brackish water bodies. They live freely on the water surface, in the intestinal contents of marine animals, or in biofilm on marine microplastics (Kirstein et al., 2016). Smolino Lake previously had a high natural salinity (up to $15 \mathrm{~g} / \mathrm{L}$ ) and was even used for balneological purposes (Chernyaeva et al., 1977). Despite anthropogenic desalination, Smolino retains the hydrochemical class characteristic in natural conditions (Zakharov, 2010), which explains the detection of vibrios in it that prefer salty waters. Unlike Vibrio non cholera, $V$. parahaemolyticus can produce a thermostable exotoxin and is a proven causative agent of acute foodborne gastroenteritis, wound infections (associated with recreational bathing), and sepsis (Matsuda et al., 2020). Found only in Smolino Lake, O. anthropi is a versatile bacterial species capable of colonizing an exceptionally wide range of habitats (Babic et al., 2000; Zurek et al., 2000; Chang et al., 2007), occurs in soil and water, is resistant to heavy metals and petroleum-hydrocarbons (AbouShanab et al., 2007; Phulpoto et al., 2021), has low virulence, and rarely causes human infection (Vila et al., 2016; Aguilera-Arreola et al., 2018).

The presence of the bacterium P. putida is a feature of the microbial communities' structure in Pervoye Lake. Along with $P$. aeruginosa, it has an extremely diverse metabolism, can convert styrene, expanded polystyrene, and oil refined products into biodegradable organic compounds (Gomes et al., 2005; Ward et al., 2006). This is crucial for Pervoye Lake, which is highly polluted by industrial wastewater and is the most polluted lake among all water bodies of Chelyabinsk city (Serebrennikova, 2010; Zakharov, 2010).

The bacterium $P$. shigelloides, was identified in the structure of the winter microorganism community only in the Shershenevskoye Reservoir. It lives in freshwater ecosystems, estuaries and in the microbiota of the inhabitants of these aquatic environments (Janda et al., 2016; Pennycook et al., 2020).

According to the depth of the sampling, the amount of oxygen, illumination, and temperature variety, we observed pronounced differences in the structure of communities between the upper and bottom levels. Most interesting and unexpected is the contribution of various factors to the variability of the structure of winter microbial communities in the water bodies of Chelyabinsk city. Specific differences in bacterial communities between the studied water bodies reflect only $30 \%$ of the structure variability. Another $10 \%$ of the variability is accounted for by the differences 
between the communities of surface and bottom level microorganisms. However, the greatest contribution (about $60 \%$ ) to the variability of the microbial community structure of lakes is made by intra-water processes, which determine the high heterogeneity of samples from different parts of the water area. We suggest that an important role in this variability belongs to the high anthropogenic load to which the water bodies of a large industrial metropolis are exposed.

\section{Conclusion}

Understanding the ecological consequences of urbanization and the role of different groups of bacteria in aquatic habitats is necessary to reduce the potential anthropogenic impact on the condition and species composition of urban bacterial communities. We assessed the composition of microbial communities in water bodies with different levels of anthropogenic load. In all studied water bodies, we identified not only the communities of bacteria that are specific to the environment but also specific taxa of anthropogenic origin. The results demonstrated that the conditions of specific water bodies and the presence of certain subpopulations of bacteria are risk factors for the emergence and spread of potentially dangerous taxa of bacteria. For example, a pathogenic species of Vibrio ( $V$. parahaemolyticus) was found in Smolino Lake.

The research demonstrates that urbanization can alter the natural microbial communities of water bodies and promote the development of certain genera of bacteria that include potential pathogens. The increased anthropogenic load leads to a change in the proportions of the ecosystem, the humanization of aquatic bacterial communities, affects the functioning of the microbial loop, and, accordingly, the biogeochemical cycle and aquatic biodiversity. It needs further research to understand the impact of urbanization fully. It is necessary to take measures to reduce the anthropogenic impact on aquatic ecosystems and compensate for the harmful effects both on humans and the environment.

The research was funded by the Russian Foundation for Basic Research (RFBR) and the Chelyabinsk Region (project No. 20-44-740003).

\section{References}

Abou-Shanab, R. A., Angle, J. S., \& van Berkum, P. (2007). Chromate-tolerant bacteria for enhanced metal uptake by Eichhornia crassipes (Mart.). International Journal of Phytoremediation, 9(2), 91-105.

Aguilar, P., Dorador, C., Vila, I., \& Sommaruga, R. (2018). Bacterioplankton composition in tropical high-elevation lakes of the Andean plateau. FEMS Microbiology Ecology, 94(3), fiy004.

Aguilera-Arreola, M. G., Ostria-Hernández, M. L., Albarrán-Fernández, E., JuárezEnriquez, S. R., Majalca-Martínez, C., Rico-Verdín, B., Ruiz, E. A., RuizPalma, M. D. S., Morales-Garcia, M. R., \& Contreras-Rodríguez, A. (2018). Correct identification of Ochrobactrum anthropi from blood culture using 16rRNA Sequencing: A first case report in an immunocompromised patient in Mexico. Frontiers in Medicine, 5, 205.

Alamri, S. (2012). Biodegradation of microcystin-RR by Bacillus flexus isolated from a Saudi freshwater lake. Saudi Journal of Biological Sciences, 19(4), 435-440.

Alon, D., Karniel, E., Zohar, I., \& Stein, G. (2018). Chryseobacterium indologenes bacteremia: Clinical and microbiological characteristics of an emerging infection. International Journal of Clinical Medicine, 9, 520-527.

Azakami, H., Nakashima, H., Akimichi, H., Noiri, Y., Ebisu, S., \& Kato, A. (2006). Involvement of N-acetyl-D-galactosamine-specific lectin in biofilm formation by the periodontopathogenic bacterium, Eikenella corrodens. Bioscience, Biotechnology, and Biochemistry, 70(2), 441-446.

Babic, I., Fischer-Le Saux, M., Giraud, E., \& Boemare, N. (2000). Occurrence of natural dixenic associations between the symbiont Photorhabdus luminescens and bacteria related to Ochrobactrum spp. in tropical entomopathogenic Heterorhabditis spp. (Nematoda, Rhabditida). Microbiology, 146(3), 709-718.

Beattie, R., Skwor, T., \& Hristova, K. (2020). Survivor microbial populations in postchlorinated wastewater are strongly associated with untreated hospital sewage and include ceftazidime and meropenem resistant populations. Science of the Total Environment, 740, 140186.

Butler, T. M., Wilhelm, A. C., Dwyer, A. C., Webb, P. N., Baldwin, A. L., \& Techtmann, S. M. (2019). Microbial community dynamics during lake ice freezing. Scientific Reports, 9(1), 6231 .
Cao, X., Wang, Y., Xu, Y., Duan, G., Huang, M., \& Peng, J. (2020). Adaptive variations of sediment microbial communities and indication of fecal-associated bacteria to nutrients in a regulated urban river. Water, 12(5), 1344.

Cavaco, M. A., St Louis, V. L., Engel, K., St Pierre, K. A., Schiff, S. L., Stibal, M., \& Neufeld, J. D. (2019). Freshwater microbial community diversity in a rapidly changing High Arctic watershed. FEMS Microbiology Ecology, 95(11), iz161.

Chang, B. V., Chiang, B. W., \& Yuan, S. Y. (2007). Biodegradation of nonylphenol in soil. Chemosphere, 66(10), 1857-1862.

Chapagain, P., Arivett, B., Cleveland, B. M., Walker, D. M., \& Salem, M. (2019). Analysis of the fecal microbiota of fast- and slow-growing rainbow trout $(\mathrm{On}$ corhynchus mykiss). BMC Genomics, 20(1), 788.

Chernyaeva, L. E., Chernyaev, A. M., \& Eremeeva, T. N. (1977). Gidrokhimiya ozer: Ural i Priural'ye [Hydrochemistry of lakes: Ural and Transurals region]. Hydrometeoisdat, Leningrad (in Russian).

Cyprowski, M., Stobnicka-Kupiec, A., Ławniczek-Wałczyk, A., Bakal-Kijek, A., Gołofit-Szymczak, M., \& Gómy, R. L. (2018). Anaerobic bacteria in wastewater treatment plant. International Archives of Occupational and Environmental health, 91(5), 571-579.

David, G. M., López García, P., Moreira, D., Alric, B., Deschamps, P., Bertolino, P., Restoux, G., Rochelle-Newall, E., Thébault, E., Simon, M., \& Jardillier, L. (2021). Small freshwater ecosystems with dissimilar microbial communities exhibit similar temporal patterns. Molecular Ecology, 30(9), 2162-2177.

Deryabina, L. V., Safonova, E. V., Bogdanov, G. O., Andreev, S. S., Yachmenev, V. A., \& Pryakhin, E. A. (2008). Biologicheskaya otsenka sostoyaniya Shershnovskogo vodokhranilishcha $\mathrm{v} 2007$ godu [Biological assessment of the state of the Shershnevsky Reservoir in 2007]. Bulletin of the Chelyabinsk State University, Series Biology, 1(4), 128-130 (in Russian).

Fàbrega, A., \& Vila, J. (2012). Yersinia enterocolitica: Pathogenesis, virulence, and antimicrobial resistance. Enfermedades Infecciosas y Microbiologia Clinica, 30(1), 24-32.

Falk, N., Reid, T., Skoyles, A., Grgicak-Mannion, A., Drouillard, K., \& Weisener, C. G. (2019). Microbial metatranscriptomic investigations across contaminant gradients of the Detroit River. Science of the Total Environment, 690, 121-131.

Gomes, N. C., Kosheleva, I. A., Abraham, W. R., \& Smalla, K. (2005). Effects of the inoculant strain Pseudomonas putida KT2442 (pNF142) and of naphthalene contamination on the soil bacterial community. FEMS Microbiology Ecology, 54(1), 21-33.

Guillier, L., Fravalo, P., Leclercq, A., Thébault, A., Kooh, P., Cadavez, V., \& Gonzales-Barron, U. (2021). Risk factors for sporadic Yersinia enterocolitica infections: A systematic review and meta-analysis. Microbial Risk Analysis, 17, 100141.

Hammer, Ø., Harper, D. A. T., \& Ryan, P. D. (2001). PAST: Paleontological statistics software package for education and data analysis. Palaeontologia Electronica, $1,1-9$.

Hlordzi, V., Kuebutomye, F. K. A., Afriyie, G., Abarike, E. D., Lu, Y., Chi, S., \& Anokyewaa, M. A. (2020). The use of Bacillus species in maintenance of water quality in aquaculture: A review. Aquaculture Reports, 18, 100503.

Huang, F., Wang, Z. H., Cai, Y. X., Chen, S. H., Tian, J. H., \& Cai, K. Z. (2018). Heavy metal bioaccumulation and cation release by growing Bacillus cereus RC-1 under culture conditions. Ecotoxicology and Environmental Safety, 157, 216-226.

Huang, L., Zhao, T., He, Y., Liu, Y., Liu, C., Jin, D., \& Jia, X. (2017). 两株绿胘杆菌对石油污染土壤的修复作用 [Bioremediation of oilcontaminated field by two Pseudomonas aeruginosa strains]. Chinese Journal of Biotechnology, 33(6), 957-967 (in Chinese).

Hubert, F., Rodier, M. H., Minoza, A., Portet-Sulla, V., Cateau, E., \& Brunet, K. (2021). Free-living amoebae promote Candida auris survival and proliferation in water. Letters in Applied Microbiology, 72(1), 82-89.

Iliev, I., Yahubyan, G., Marhova, M., Apostolova, E., Gozmanova, M., Gecheva, G., Kostadinova, S., Ivanova, A., \& Baev, V. (2017). Metagenomic profiling of the microbial freshwater communities in two Bulgarian reservoirs. Journal of Basic Microbiology, 57(8), 669-679.

Izrael-Živković, L., Beškoski, V., Rikalović, M., Kazazić, S., Shapiro, N., Woyke, T., Gojgić-Cvijović, G., Vrvić, M. M., Maksimović, N., \& Karadžić, I. (2019). High-quality draft genome sequence of Pseudomonas aeruginosa san ai, an environmental isolate resistant to heavy metals. Extremophiles: Life Under Extreme Conditions, 23(4), 399-405.

Janda, J., Abbott, S., \& McIver, C. (2016). Plesiomonas shigelloides revisited. Clinical Microbiology Reviews, 29(2), 349-374.

Ji, B., Liang, J., Ma, Y., Zhu, L., \& Liu, Y. (2019). Bacterial community and eutrophic index analysis of the East Lake. Environmental Pollution, 252, 682-688.

Kang, D., \& Kirienko, N. V. (2018). Interdependence between iron acquisition and biofilm formation in Pseudomonas aeruginosa. Journal of Microbiology, 56(7), $449-457$.

Kiama, C., Njire, M., Kambura, A., Mugweru, J., Matiru, V., Wafula, E., Kagali, R. N., \& Kuja, J. O. (2021). Prokaryotic diversity and composition within equatorial lakes Olbolosat and Oloiden in Kenya (Africa). Current Research in Microbial Sciences, 2, 100066. 
Kiersztyn, B., Chróst, R., Kaliński, T., Siuda, W., Bukowska, A., Kowalczyk, G., \& Grabowska, K. (2019). Structural and functional microbial diversity along a eutrophication gradient of interconnected lakes undergoing anthropopressure. Scientific Reports, 9(1), 11144.

Kim, S., Jeon, H., Han, H., \& Hur, J. (2021). Evaluation of Bacillus albus SMG-1 and B. safensis SMG-2 isolated from Saemangeum Lake as probiotics for aquaculture of white shrimp (Litopenaeus vannamei). Aquaculture Reports, 20, 100743.

Kirstein, I. V., Kirmizi, S., Wichels, A., Garin-Fernandez, A., Erler, R., Löder, M., \& Gerdts, G. (2016). Dangerous hitchhikers? Evidence for potentially pathogenic Vibrio spp. on microplastic particles. Marine Environmental Research, 120, 1-8.

Kuebutornye, F., Abarike, E. D., \& Lu, Y. (2019). A review on the application of Bacillus as probiotics in aquaculture. Fish and Shellfish Immunology, 87, 820 828.

Kumari, S., \& Das, S. (2019). Expression of metallothionein encoding gene bmtA in biofilm-forming marine bacterium Pseudomonas aeruginosa N6P6 and understanding its involvement in $\mathrm{Pb}$ (II) resistance and bioremediation. Environmental Science and Pollution Research Intemational, 26(28), 28763-28774.

Li, J., Ouyang, X., \& Zhu, X. (2021). Land space simulation of urban agglomerations from the perspective of the symbiosis of urban development and ecological protection: A case study of Changsha-Zhuzhou-Xiangtan urban agglomeration. Ecological Indicators, 126, 107669.

Lim, W. G., Tong, T., \& Chew, J. (2020). Chryseobacterium indologenes and Chryseobacterium gleum interact and multiply intracellularly in Acanthamoeba castellanii. Experimental Parasitology, 211, 107862.

Liu, C., Minor, E., Garfinkel, M., Mu, B., \& Tian, G. (2021). Anthropogenic and climatic factors differentially affect waterbody area and connectivity in an urbanizing landscape: A case study in Zhengzhou, China. Land, 10(10), 1070.

Liu, K., Hou, J., Liu, Y., Hu, A., Wang, M., Wang, F., Chen, Y., \& Gu, Z. (2019). Biogeography of the free-living and particle-attached bacteria in Tibetan lakes. FEMS Microbiology Ecology, 95(7), fiz088.

Lucero-Estrada, C., Favier, G., \& Escudero, M. (2020). An overview of Yersinia enterocolitica and related species in samples of different origin from San Luis, Argentina. Food Microbiology, 86, 103345.

Manikkam, R., Imchen, M., Kaari, M., Angamuthu, V., Venugopal, G., \& Thangavel, S., Joseph, J., Ramasamy, B., \& Kumavath, R. (2020). Metagenomic insights unveil the dominance of undescribed Actinobacteria in pond ecosystem of an Indian shrine. Meta Gene, 23, 100639.

Mathai, P., Dunn, H., Magnone, P., Zhang, Q., Ishii, S., Chun, C., \& Sadowsky, M. (2019). Association between submerged aquatic vegetation and elevated levels of Escherichia coli and potential bacterial pathogens in freshwater lakes. Science of the Total Environment, 657, 319-324.

Matsuda, S., Hiyoshi, H., Tandhavanant, S., \& Kodama, T. (2020). Advances on Vibrio parahaemolyticus research in the postgenomic era. Microbiology and Immunology, 64(3), 167-181.

McLoughlin, S., Spillane, C., Claffey, N., Smith, P. E., O’Rourke, T., Diskin, M. G., \& Waters, S. M. (2020). Rumen microbiome composition is altered in sheep divergent in feed efficiency. Frontiers in Microbiology, 11, 1981.

Mueller-Spitz, S. R., Stewart, L. B., Klump, J. V., \& McLellan, S. L. (2010). Freshwater suspended sediments and sewage are reservoirs for enterotoxin-positive Clostridium perfringens. Applied and Environmental Microbiology, 76(16), $5556-5562$.

Müller, N., Scherag, F., Pester, M., \& Schink, B. (2015). Bacillus stamsii sp. nov., a facultatively anaerobic sugar degrader that is numerically dominant in freshwater lake sediment. Systematic and Applied Microbiology, 38(6), 379-389.

Nevers, M., Byappanahalli, M., Nakatsu, C., Kinzelman, J., Phanikumar, M., Shively, D., \& Spoljaric, A. (2020). Interaction of bacterial communities and indicators of water quality in shoreline sand, sediment, and water of Lake Michigan. Water Research, 178, 115671.

Nnadozie, C. F., \& Odume, O. N. (2019). Freshwater environments as reservoirs of antibiotic resistant bacteria and their role in the dissemination of antibiotic resistance genes. Environmental Pollution, 254(B), 113067.

Nokhrin, D. Y., Gribovsky, Y. G., \& Davydova, N. A. (2018). Correlation adaptometry of microelement composition of tissues as a method of estimation of the environmental stress (on the example of populations of commercial fishes from mineralized water). Questions of Legal Regulation in Veterinary Medicine, 4, 225-230.

Nokhrin, D. Y., Gribovsky, Y. G., Davydova, N. A., \& Korlyakov, K. A. (2020). Shershnevskoye vodokhranilische [Shershnevskoe reservoir]. In: Nokhrin, D. Y. (Ed.). Ekologicheskoye i veterinarno-sanitarnoye sostoyaniye vodoyemov Chelyabinskoy oblasti [Ecological and veterinary-sanitary state of water reservoirs in the Chelyabinsk Region]. New Format, Ekaterinburg, Barnaul. Pp. 68-93 (in Russian).

Numberger, D., Ganzert, L., Zoccarato, L., Mühldorfer, K., Sauer, S., Grossart, H. P., \& Greenwood, A. D. (2019). Characterization of bacterial communities in wastewater with enhanced taxonomic resolution by full-length 16S rRNA sequencing. Scientific Reports, 9(1), 9673.
Okabe, S., Okayama, N., Savichtcheva, O., \& Ito, T. (2007). Quantification of hostspecific Bacteroides-Prevotella 16S rRNA genetic markers for assessment of fecal pollution in freshwater. Applied Microbiology and Biotechnology, 74(4), $890-901$.

Osipov, G. A., Boiko, N. B., Fedosova, N. F., Kasikhina, S. A., \& Lyadov, K. V. (2009). Comparative gas chromatography-mass spectrometry study of the composition of microbial chemical markers in feces. Microbial Ecology in Health and Disease, 21, 159-171.

Pennycook, K., Pennycook, K., McCready, T., \& Kazanowski, D. (2020). Severe cellulitis and bacteremia caused by Plesiomonas shigelloides following a traumatic freshwater injury. Idcases, 19, e00637.

Penton, M., 3rd, Oraa, S. S., Abdelhemid, A., Otto, C., \& Hammerschlag, M. R. (2020). Head and neck infections in children due to Eikenella corrodens: Report of three cases and review of literature. International Journal of Pediatric Otorhinolaryngology, 138, 110287.

Phulpoto, I., Hu, B., Wang, Y., Ndayisenga, F., Li, J., \& Yu, Z. (2021). Effect of natural microbiome and culturable biosurfactants-producing bacterial consortia of freshwater lake on petroleum-hydrocarbon degradation. Science of the Total Environment, 751, 141720.

Qu, J., Jia, C., Liu, Q., Li, Z., Liu, P., Yang, M., Zhao, M., Li, W., Zhu, H., \& Zhang, Q. (2018). Dynamics of bacterial community diversity and structure in the terminal reservoir of the South-To-North Water Diversion Project in China. Water, 10(6), 709.

Rajakumar, S., Ayyasamy, P. M., Shanthi, K., Thavamani, P., Velmurugan, P., Song, Y. C., \& Lakshmanaperumalsamy, P. (2008). Nitrate removal efficiency of bacterial consortium (Pseudomonas sp. KW1 and Bacillus sp. YW4) in synthetic nitrate-rich water. Journal of Hazardous Materials, 157, 553-563.

Ramírez, V., Baez, A., López, P., Bustillos, R., Villalobos, M. Á., Carreño, R., \& Munive, J. A. (2019). Chromium hyper-tolerant Bacillus sp. MH778713 assists phytoremediation of heavy metals by mesquite trees (Prosopis laevigata). Frontiers in Microbiology, 10, 1833.

Ramos, M. S., Furlan, J., Gallo, I., Dos Santos, L., de Campos, T. A., Savazzi, E. A., \& Stehling, E. G. (2020). High level of resistance to antimicrobials and heavy metals in multidrug-resistant Pseudomonas sp. isolated from water sources. Current Microbiology, 77(10), 2694-2701.

Reid, T., Droppo, I. G., \& Weisener, C. G. (2020). Tracking functional bacterial biomarkers in response to a gradient of contaminant exposure within a river continuum. Water Research, 168, 115167.

Ren, Z., Wang, F., Qu, X., Elser, J. J., Liu, Y., \& Chu, L. (2017). Taxonomic and functional differences between microbial communities in Qinghai Lake and its input streams. Frontiers in Microbiology, 8, 2319.

Rodríguez-Rojas, L., Suarez-López, A., Cantón, R., \& Ruiz-Garbajosa, P. (2020). Eikenella corrodens causing deep-seated infections. Six-year experience in a University Hospital in Madrid. Enfermedades Infecciosas y Microbiologia Clinica, 38(2), 76-78.

Sagova-Mareckova, M., Boenigk, J., Bouchez, A., Cermakova, K., Chonova, T., Cordier, T., Eisendle, U., Elersek, T., Fazi, S., Fleituch, T., Frühe, L., Gajdosova, M., Graupner, N., Haegerbaeumer, A., Kelly, A. M., Kopecky, J., Leese, F., Nõges, P., Orlic, S., Panksep, K., Pawlowski, J., Petrusek, A., Piggott, J. J., Rusch, J. C., Salis, R., Schenk, J., Simek, K., Stovicek, A., Strand, D. A., Vasquez, M. I., Vralstad, T., Zlatkovic, S., Zupancic, M., \& Stoeck, T. (2021). Expanding ecological assessment by integrating microorganisms into routine freshwater biomonitoring. Water Research, 191, 116767.

Serebrennikova, Y. A. (2010). Kriticheskiye osobennosti indikatora nekotorykh vodoyemov goroda Chelyabinska [Critical indicator features of some reservoirs of the city of Chelyabinsk]. Siberian Journal of Life Sciences and Agriculture, 6(1), 293-296 (in Russian).

Sharma, B., \& Shukla, P. (2021). Lead bioaccumulation mediated by Bacillus cereus BPS-9 from an industrial waste contaminated site encoding heavy metal resistant genes and their transporters. Joumal of Hazardous Materials, 401, 123285.

Sokal, R. R., \& Rohlf, F. J. (1995). Biometry: The principles and practice of statistics in biological research. Freeman \& Co., New York.

Tadese, D., Sun, C., Liu, B., Muritu, R., Kevin, N., \& Zhou, Q., Zhu, L., Zhang, H., Bo, L., Liu, M., Xu, H. (2020). Combined effects of emodin and Clostridium butyricum on growth and non-specific immunity of giant freshwater prawns, Macrobrachium rosenbergii. Aquaculture, 525, 735281.

Tanaka, M., Araki, K., Higuchi, H., Fukuoka-Araki, K., Horikoshi, Y., \& Hataya, H. (2020). Pediatric acute dacryocystitis due to Eikenella corrodens: A case report. Journal of Infection and Chemotherapy, 26(5), 510-512.

Tanzadeh, J., Ghasemi, M. F., Anvari, M., \& Issazadeh, K. (2020). Biological removal of crude oil with the use of native bacterial consortia isolated from the shorelines of the Caspian Sea. Biotechnology and Biotechnological Equipment, 34(1), 361-374.

Tian, L., Yan, Z., Wang, C., Xu, S., \& Jiang, H. (2021). Habitat heterogeneity induces regional differences in sediment nitrogen fixation in eutrophic freshwater lake. Science of the Total Environment, 772, 145594. 
Vadde, K., Feng, Q., Wang, J., McCarthy, A., \& Sekar, R. (2019). Next-generation sequencing reveals fecal contamination and potentially pathogenic bacteria in a major inflow river of Taihu Lake. Environmental Pollution, 254, 113108.

Varjani, S., Upasani, V. N., \& Pandey, A. (2020). Bioremediation of oily sludge polluted soil employing a novel strain of Pseudomonas aeruginosa and phytotoxicity of petroleum hydrocarbons for seed germination. Science of the Total Environment, 737, 139766

Vierheilig, J., Frick, C., Mayer, R. E., Kirschner, A. K., Reischer, G. H., Derx, J., Mach, R. L., Sommer, R., \& Farnleitner, A. H. (2013). Clostridium perfringens is not suitable for the indication of fecal pollution from ruminant wildlife but is associated with excreta from nonherbivorous animals and human sewage. Applied and Environmental Microbiology, 79(16), 5089-5092.

Vila, A., Pagella, H., Vera Bello, G., \& Vicente, A. (2016). Brucella suis bacteremia misidentified as Ochrobactrum anthropi by the VITEK 2 system. Journal of Infection in Developing Countries, 10(4), 432-436.

Wahl, H., Raudabaugh, D., Bach, E., Bone, T., Luttenton, M., Cichewicz, R., \& Miller, A. (2018). What lies beneath? Fungal diversity at the bottom of Lake Michigan and Lake Superior. Journal of Great Lakes Research, 44(2), 263-270.

Wang, N., Jiang, M., Zhang, P., Shu, H., Li, Y., Guo, Z., \& Li, Y. (2020). Amelioration of Cd-induced bioaccumulation, oxidative stress and intestinal microbiota by Bacillus cereus in Carassius auratus gibelio. Chemosphere, 245, 125613.

Ward, P. G., Goff, M., Donner, M., Kaminsky, W., \& O'Connor, K. E. (2006). A two-step chemo-biotechnological conversion of polystyrene to a biodegradable thermoplastic. Environmental Science and Technology, 40(7), 2433-2437.

Wu, M., Liang, J., Tang, J., Li, G., Shan, S., Guo, Z., \& Deng, L. (2017). Decontamination of multiple heavy metals-containing effluents through microbial biotechnology. Journal of Hazardous Materials, 337, 189-197.

Xie, E., Zhao, X., Li, K., Zhang, P., Zhou, X., \& Zhao, X. (2021). Microbial community structure in the river sediments from upstream of Guanting Reservoir: Potential impacts of reclaimed water recharge. Science of the Total Environment, 766,142609
Yadav, N., Kour, D., \& Yadav, A. N. (2018). Microbiomes of freshwater lake ecosystems. Journal of Microbiology and Experimentation, 6(6), 245-248.

Yang, Y., Chen, J., Tong, T., Xie, S., \& Liu, Y. (2020). Influences of eutrophication on methanogenesis pathways and methanogenic microbial community structures in freshwater lakes. Environmental Pollution, 260, 114106.

Yin, Y., Zhang, P., Yue, X., Du, X., Li, W., Yin, Y., Yi, C., \& Li, Y. (2018). Effect of sub-chronic exposure to lead $(\mathrm{Pb})$ and Bacillus subtilis on Carassius auratus gibelio: Bioaccumulation, antioxidant responses and immune responses. Ecotoxicology and Environmental Safety, 161, 755-762.

Yue, Y., Wang, F., Fu, Z., Tang, Y., Ma, J., Qin, Y., Yang, M., \& Chen, X.-P. (2020). Differential response of microbial diversity and abundance to hydrological residual time and age in cascade reservoirs. Journal of Soils and Sediments, 21(2), 1290-1301.

Zakharov, S. G. (2014). Ekosistema ozera Chebarkul do i posle padeniya meteorita [Ecosystem of Lake Chebarkul before and after the fall of the meteorite]. Edge Ra, Chelyabinsk (in Russian).

Zakharov, S. G., \& Likhachev, S. F. (2008). Dinamika i sovremennoye sostoyaniye osnovnykh geoekologicheskikh parametrov ozera Smolino [Dynamics and the current state of the main geoecological parameters of Lake Smolino]. Bulletin of the Chelyabinsk State University, Ecology, Environmental Management, 17, 62-68 (in Russian)

Zakharov, S. G. (2010). Ozera Chelyabinskoy oblasti [Lakes of the Chelyabinsk region]. Abris, Chelyabinsk (in Russian).

Zhang, L., Zhao, T., Wang, Q., Li, L., Shen, T., \& Gao, G. (2019). Bacterial community composition in aquatic and sediment samples with spatiotemporal dynamics in large, shallow, eutrophic Lake Chaohu, China. Journal of Freshwater Ecology, 34(1), 575-589.

Zurek, L., Schal, C., \& Watson, D. W. (2000). Diversity and contribution of the intestinal bacterial community to the development of Musca domestica (Diptera: Muscidae) larvae. Journal of Medical Entomology, 37(6), 924-928. 